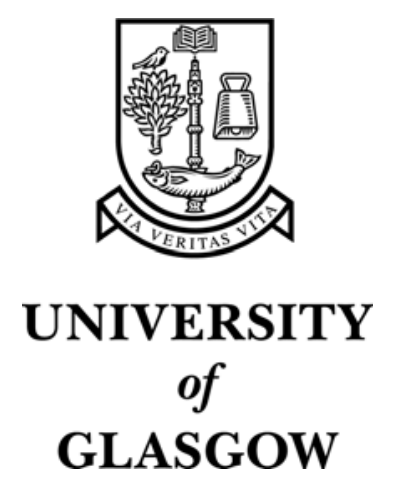

Clayton, P. Imperialism and colonialism. In Enemies and passing friends: settler ideologies in twentieth-century Ulster, Chap 1, pages pp. 9-32. London: Pluto Press (1996)

http://eprints.gla.ac.uk/2810/ 


\title{
Enemies and Passing Friends
}

\author{
Settler Ideologies in Twentieth Century Ulster
}

\author{
Pamela Clayton
}

Published, with bibliography, in 1996 by Pluto Press, London and East Haven, CT

IBSN 0745310117 Preface 


\section{Imperialism and colonialism}

Many who see the Northern Ireland problem as the result of imperialism frequently overlook the fact that, although the territory was indeed originally part of the British expropriation of Ireland, it has remained under British jurisdiction largely because of the size and determined resistance of its settler population. Imperialism and settler colonialism in general are not identical; and in respect to the 'native' peoples, the imperial ideology of the metropolis has differed in important ways from the colonial ideology of settlers. The British and French empires have been the most extensively studied in this context, both being particularly relevant because they included two important settler colonies which fiercely resisted majority rule, namely Southern Rhodesia and Algeria. Works on the Spanish, Portuguese, Dutch, German and Belgian empires, however, draw very similar conclusions to those on the British and French (Alatas 1977:7).

The term 'imperialism', which was coined in 1858 to mean 'despotism', changed in 1881 to take on the meaning 'principle or spirit of empire; advocacy of imperial interests' in 1881 (Shorter Oxford English Dictionary 1959). To this could be added Lord Rosebery's definition, 'greater pride in Empire' (Eldridge 1978:3). It is probably misleading to apply the term indiscriminately to the whole of the four hundred or so years of modern European expansionism. This ranged from the plunder empires of the sixteenth through the settlement colonies of the seventeenth and eighteenth to the tropical empires of the nineteenth century. The 'spirit of empire' of the latter, with its certainty, conceit and confidence, was very different form the critical self-evaluation and humbling cultural comparison of the previous two centuries when confronted with much older civilisations such as India, and from the self-doubt of the twentieth century (Faber 1966:45; Betts 1976:150).

The form of empire also changed. By the eighteenth century both British and French empires had evolved into a system based on the political ascendancy of the metropolis with its 
dependent white settler colonies, first in North America and later in Australia and New Zealand. These existed for the economic well-being of the 'mother country', and consisted of a large settler population and a small 'native' population, considered unimportant especially when nomadic and marginalised by extermination or by herding on to reserves. The late nineteenth century, however, saw European nations adding to their previous conquests in the East almost the whole of Africa, where populous and settled societies had long existed.

Whether the primary motive for empire was strategic or economic is still debated; but whatever the motivation, imperialism in practical terms was still the exercise of power, economic and political. It was, however, only from the nineteenth century onwards that naked power was dressed up in the 'respectable' garb of European responsibility for the progress of backward peoples. An age which had seen the American and French Revolutions based on principles of liberty and equality needed to justify its seizure of land and mastery of areas which were already inhabited by large numbers of indigenes (Thornton 1965:11). The principle of 'trusteeship' served to justify the European hold on power over subject peoples, and side-stepped that fact that these, in the vast majority of cases, had neither invited nor showed much sign of appreciating this European interest in their well-being.

The keyword in this self-justification was civilisation: the civilising mission was the duty of European nations to share their advances with the backward and barbarian parts of the world. Civilisation, of course, meant European languages, religion, and politico-legal systems. Above all European technological superiority was taken as proof of cultural superiority, although the extent of the technological gap was greatly exaggerated. In reality, this gap had opened for many peoples only in the eighteenth century (Alatas 1978:216). Nevertheless, since no reasonable person could reject the 'gift' Europeans brought, this reinterpretation of imperial power made it possible to interpret dissent as no more than the work of agitators (Worsley 1967:68).

Interpretations of European superiority ranged from humanitarian to racist. The existence of these competing doctrines of imperialism documented by Thornton (1965) can be seen in the shifts back and forth in the dominant ideology of empire during the nineteenth and twentieth 
centuries. The universalistic and liberal ideas which saw all people as equal in the earlier part of the nineteenth century gave way gradually to racism in thought and practice. Feelings of British racial uniqueness, imaginatively traced back to fifth-century Anglo-Saxon society, led to assumptions of racial and national moral superiority. These both helped to inspire the imposition of imperial rule over 'inferior' peoples and to serve as justification for it. Such notions took a different form under French rule. It was French 'culture' rather than the French 'race' which was held superior; but the belief that France was the true guardian of civilisation, the resulting contempt for the indigenous cultures under their rule and their actual practice of imperial rule had a similar end-result to the avowedly racist British imperialist ideology.

So in both empires, the notion evolved that European languages and culture were the only vehicles for progress. A series of insurrections such as the Indian rebellion of 1857 emphasised the need for order and at the same time 'proved' that indigenous society was unfit for self-rule. Earlier notions of strictly limited liability for the imperial power were dropped - 'natives' had a right (however theoretical) to law, to protection, to a measure of education - but not to selfdetermination.

Another difference between the nineteenth and earlier centuries was that white settlements in Africa formed 'mixed' colonies, with minority populations of settlers and adventurers setting up colonies of white domination over the existing inhabitants, who were numerically superior but whose weapons were no match for the Maxim gun. In this situation, the settlers attempted to create societies similar to that of the metropolis (Fieldhouse 1966:11). This became a logical impossibility, for by the late nineteenth century the franchise was beginning to be extended in the European metropoles (which in any case did not consist of a small recognisably foreign elite subordinating a large 'native' majority). The contradiction did not have to be addressed, however, as long as the 'native' majority acquiesced in their subordination.

Metropolitan British and French attitudes to these mixed colonies show some ambivalence. 
In principle, they were treated in the same way as other colonies, but the presence of settlers certainly made a difference. Although French colonial possessions were generally subordinated to the metropolis politically, according to Fanon (1965:180) it was the rapacity and racism of the French settlers which increased the impact of French imperialism. Even non-settler British possessions were administered in a much more decentralised way, following the principles of the Durham Report, which pronounced that people in the colonies were the best fitted to run them. The 'people in the colonies', however, were the white settlers and imperial representatives, not the 'natives', and in practice, the system of 'collaboration' between settlers and their metropolis was even looser than imperial control over other dependencies (Denoon 1983:66). Furthermore, the British were less 'liberal' about social relationships with colonised peoples. Both French settlers and officials were far less racially exclusive and much more indulgent to sexual relations between Europeans and 'natives'.

Although France shared with other European nations the quest for new markets, it had a declining birth-rate and no need to shed surplus labour. Hence Algeria was the only important settlement colony, and although there was very substantial state involvement in its conquest, this was prompted chiefly by economic pressure from settlers. The nineteenth-century British government did not set out to create mixed settlement colonies, although it ended up with some, founded by individuals or groups seeking their own advantage. Yet settlement colonies had their uses for the metropolis. For example, some British imperialists argued that exporting some of the glut of labourers and malcontents would preserve social stability, and that new markets and raw materials generated by settler enterprise would relieve domestic unemployment. Edward Gibbon Wakefield pointed out that overseas colonies might also serve to:

turn the tide of Irish emigration from England to her colonies; not to mention that the owners of land in Ireland, most of them being foreigners by religion, might thus be taken out of the dilemma in which they are now placed: that of a choice between legally giving up a great part of their rental to the hungry people, and yielding to the people's violence the land which was taken by violence from their fathers (cited in Winks 1969:47-8).

Settlers were also built into the British ideological model of empire and the true character of the British 'race'. An image was painted of the ennobling effects of living in open space far from 
the metropolis, allowing 'dynamic action and personal fulfilment'. The colonial personality was free, noble and energetic, moulded according to Curzon 'in the furnace of responsibility and on the anvil of self-reliance' (Betts 1976:15, 16). There was a strong feeling that life in Europe had become too materialistic: colonial life had an elevating moral purpose which would improve the national character (Ridley 1983:59-60, 103). Migration would also establish enduring sentimental ties within the empire. For Seeley this empire was an enlargement of England that made her a leading state instead of the small nation she would otherwise be, so the white settlements (and India, for other reasons) had to be retained (Faber 1966:59, 65).

The establishment of mixed colonies also contained the seeds of future metropolitan unease, and some imperialists were more wary of settlers. Merivale was wholeheartedly devoted to the notion of British settlers maintaining British supremacy throughout the globe, but he was unimpressed with the new colonies. In a lecture published in 1861 he scolded them for living in the past, in the society which they had left, and in the future, the society they dreamt of, and therefore not giving much thought to forming carefully thought-out and permanent institutions in the present. Instead, he complained, they let institutions grow up carelessly and framed laws merely for actual emergencies (Winks 1969:86). It has been argued more recently that metropolitan governments were obliged to take under their flags many of the territories carved out by settlers, in order to 'direct this world revolution along orderly paths and to control the boundless, irresponsible, freebooting and destructive enterprises of pioneers and adventurers' (Lüthy 1964:32-3).

Certainly the 'national interest' of the metropolis was not necessarily the same as the more immediate and personal interests of the colonial adventurers; and what happened in the colonies was often beyond imperial control, including the unauthorised take-over of territory. The settlement of Southern Rhodesia is an example of this. Rhodes in an election speech in South Africa in 1898 summed up his view of the imperial government's role:

We are not going to be governed from home ... we do everything. We pass a Bill and the Queen just puts her name to it ... what she does for us, and without our paying for it, is this: she protects us with her fleet, and when I take a new country for you she protects me from the German and the 
Frenchman ... Whenever I took a country I simply said to the Queen: "I have taken that: you must put your flag over it" (cited in Huttenback 1975:109).

This view was substantially accurate. However, although the creation of Southern Rhodesia is commonly attributed to the arch-imperialist Rhodes and his British South Africa Company, it is clear from the contemporary literature that it was the settlers who took the major part in determining the course of Rhodesian history (see, for example, Hone 1909; Hole 1928; Hickman 1960; Olivier 1975). It was they, not Rhodes, who shared their living space with the indigenous population and it was in the settlers' own interests to gain as much economic and political power for themselves as they could. Rhodes' ideology, especially in his later years, was that of the imperialist rather than of the settler, though like other imperialists, he found it impossible to control 'his' settlers in their conflict with the Matabele (Huttenback 1975:108), however much settler behaviour contravened the imperial ideal of the civilising mission.

Settlers had their merits and settler colonies their usefulness, especially in helping to paint the globe red; but imperial statesmen generally had a lofty attitude towards them: 'They constituted a lesser rank in society' (Thornton 1965:41). Equally, settlers had an ambivalent attitude towards the 'mother country'. They gloried in its achievements and claimed to be the only local representatives of its culture, civilisation and values; but they were as wary of the imperial government as it was of them. Settler views of the metropolis were coloured by perceptions of metropolitan greed, incompetence or arrogance, and by the awareness that their own interests were diverging from those of the mother country. Attempts at direct imperial control aroused violent settler reaction. Memmi in The Coloniser and the Colonised (1974:65) sums up the ambiguity of relations with the mother country: 'These exaltation-resentment dialectics uniting the colonialist to his homeland give a peculiar shade to the nature of his love for it'.

Kipling's work exemplifies some of these feelings. He seems to have loved the empire but not England, and in 'The Native-Born' (1894) he despairs of 'our English brother (But he does not understand)' (in Winks 1969:14). The English attitude to the empire was unenlightened in comparison to that of men of the frontier like himself; and in Puck of Pook's Hill, where the 
Roman empire is an emblem for the British, it is the stern men of the frontier who defend the boundaries against barbarian attack. The troops from Rome are effeminate and decadent, and there is growing social crisis in the capital. These views were echoed by many other colonial writers from France and Germany as well as Britain. The contradiction between the notion of 'civilisation' and the 'decadence' of the metropolis which was its fount rarely, however, led settlers or colonial writers to question the value of imperialism. Outside his fiction Kipling campaigned for a strong army and told soldiers that their duty was not to any politician or party but to the empire and the white race. Yet at the same time, though the imperial frontiers might form his noblest subject-matter, the best place for a writer to live was England, with its intellectual tradition, the company of fellow-writers and large numbers of readers. These were luxuries not commonly found in the settlement colonies, where the ethos of 'action' was allied with contempt for intellectualism.

Generally, however, it was only when settler colony and metropolis clashed on specific points that the relationship became overtly strained; and even then settler demands for independence were very much a last resort. In the twentieth century, such problems were often solved by alternatives such as Dominion status or legal incorporation into the metropolis. It was quite possible for settlers to grow attached to their new land while remaining within the empire, and 'though habitually disobedient, European settlers were also instinctively loyal' (Fieldhouse 1966:396). There was, however, one feature which distinguished the new British Dominions from other settler colonies: in the latter, settlers remained small if dominant minorities and hence Dominion status was barred to them.

Despite this disappointment, settlers both in Kenya and Rhodesia, as remarked by Michael Blundell, himself a Kenyan settler, when 'about to indulge in some desperate action to demonstrate their contempt for Colonial Office rule, (...) invariably prefaced it by singing God Save the Queen at the same time to show their loyalty' (cited in Thornton 1978:283). White settlers saw themselves as more loyal than the inhabitants of the metropolis. Only they faced directly the threat from the 'natives'. British troops were welcome when they were sent to protect 
settlers against the 'natives' but when they tried to protect 'natives' the metropolis and its troops were regarded as 'a tyrannical imposition' (Baker 1983:54). Thus settler loyalty was conditional on being allowed to deal with 'native affairs' themselves. It is hardly surprising then that the occasions when settler-metropolitan conflict could not be resolved peacefully arose over the issue of the transfer of political power to the hitherto powerless 'natives'. It was in such circumstances that loyalty became such an issue that 'overt attention must to paid to invoking (it)' (Field 1982:239). Settler loyalty, however, was essentially to the late nineteenth-century metropolis, not to that of the 1950s and 1960s: in other words, it was loyalty to a nation still largely committed to the maintenance of empire - a nation which no longer existed.

Settlers also tended to claim that the majority in the colony was 'disloyal'. The British minority in Lower Canada did this vis-à-vis the French (Boyce 1970:101), and in other British colonies 'natives' rebelling against being dispossessed of their own lands were often accused of disloyalty to the imperial power. Such claims were heightened when there was a settler minority whose dominance was threatened by the metropolis itself. Claims of 'loyalty' to something higher than the government or parliament of the metropolis became a justification for the pursuit of aims which contravened both those of the metropolis and of the 'natives'. For all these reasons, a stress on loyalty is generally characteristic of settlers.

Identity is another issue in settler societies. Louis Hartz, in his seminal work, The Founding of New Societies (1964:11-13, 53-4), observed that identity formation by European settlers in a new land is a complex process. Changes in Europe and the presence of 'native' peoples in the new land make it difficult to maintain identification with the old country. The 'racial element' becomes an integral part of settler consciousness and national identity in a way that does not occur in Europe. The settlers in Hartz's study, however, eventually won political independence from the motherland; colonists in North Africa did not, and 'conceding no merits to the colonial community, recognising neither its traditions, nor its laws, nor its ways, he cannot acknowledge belonging to it himself ... The result is that the colonialist is unsure of his true nationality' (Memmi 1974:68). Religion was, however, another kind of identity available. Although here the 
reference is to the colonised, it is equally applicable to some settler groups:

With its institutional network, its collective and periodic holidays, religion constitutes another refuge value, both for the individual and for the group. For the individual it is one of the rare paths of retreat; for the group it is one of the rare manifestations which can protect its original existence ... Formalism, of which religious formality is only one aspect, is the cyst into which colonial society shuts itself and hardens, degrading its own life in order to save it. It is a spontaneous action of self-defence, a means of safe-guarding the collective consciousness without which a people quickly cease to exist (Memmi 1974:101-2).

However it is formed, the concept of identity has been seen as one which has peculiar relevance where groups are in competition:

Group consciousness or identity occurs when a group recognises itself as possessing unique attributes that distinguish it from others ... (It) assumes greater saliency when groups compete for scarce resources, power or other desired goods, but group awareness also emerges when groups perceive their valued attributes (for example culture, religion, language, identity) threatened by the actions of others, be that threat real or imagined (Baker 1983:10-11).

Since settler loyalty depends on retaining control of 'native' policy, any divergence between settlers and the metropolis on this issue leads to major strains in the relationship; and one of the most significant divergences between colonial and imperial ideology arose precisely from conflicting attitudes towards 'native' peoples.

Imperial and colonial ideology had always diverged to some extent, owing to the conflicting economic and strategic interests of the metropolis and the settlement, leading to conflicts such as the American War of Independence. 'Native policy', usually involving their subordination and control, was sometimes in the interests of both metropolis and settlers, and not therefore a common source of conflict. Even so, as early as the eighteenth century, the British government had attempted to protect Amerinds and French settlers against the British colonists (Faber 1966:49).

From the nineteenth century onwards, however, the very 'civilising mission' which legitimated imperial conquest and control brought to the fore the issue of 'native policy'. The 'white man's burden' meant that, in imperialist theory and to some extent in practice, 'native policy' involved the role of the Colonial Office as guardian of 'racial' minorities and 'backward' peoples. In the 
mixed colonies, however, it continued to mean principally the legalised theft of 'native' land and the use of 'natives' as a source of cheap labour. Settler societies were therefore quick to seek political autonomy in order to deal with the 'natives' in their own way and acquire what territory they wanted. Hence the nineteenth century saw a further divergence between colonial and imperial ideology. Two contradictory sets of principles were on a collision course within the settlements: the concept of trusteeship within the imperial philosophy of a non-racial empire, and the settlers' determination to create a 'White Man's Country' (Huttenback 1976:21).

Some in the metropolis appreciated these conflicting aims. Philanthropic and religious groups lobbied the government to curtail settler aggression; and the case of New Zealand shows that the imperial government was aware of the dangers (already proved in Tasmania and Australia) of white settler power. Until 1849 the British government tried to stop large-scale settlement in New Zealand because there would inevitably be clashes with non-Europeans. The new Governor in 1856, believing that the Maoris should not be left to the mercy of the settlers, reserved the conduct of Maori affairs to the Crown. In 1865 the imperial Parliament passed the Colonial Laws Validity Act to prevent settlement colonies enacting legislation that went against British common law, and in 1870 British troops were withdrawn from New Zealand, no doubt partly to save money but also in order to make the New Zealand government face up to the consequences of antagonising the Maoris by confiscating their lands, while failing to raise their own military force against the warfare that their policy made inevitable. In the event the settlers were unable to defeat the Maoris, who were perhaps for this reason able to attain more rights than the 'natives' in any other settler state (Huttenback 1975:96).

The New Zealand case was, however, exceptional. Metropolitan withdrawal usually left indigenes at the mercy of settlers. The proclaimed British intention of protecting 'native' people was undermined partly by the practical difficulties for an over-stretched empire of controlling distant settler colonies; but there were also contradictions at the heart of British imperial policy. British settlement areas were regarded as individual societies with their own destinies though bound, in the case of settlers only, to the imperial family by ties of blood; so there was an 
underlying feeling that they should have a fair degree of autonomy. In addition, by the 1850s demands for economy in imperial government expenditure led to the grant of responsible government to a number of settler states, despite the presence of unrepresented 'native' peoples. Thus there was an early contradiction between imperial rhetoric and imperial action.

The British failure to protect 'native' interests against settlers was most apparent in settlerfarmer societies, and here the colonial situation was at its most explosive: 'The confrontation is not only total, it is also peculiarly direct, and the antagonisms fall along the same line of division in every sphere of relationship between White and colonised' (Worsley 1967:49). The greater the land hunger the greater the drive to repel or crush the resident population, using the traditional settlers' claim that they would make more efficient use of the land for the benefit of all, a claim made with particular force when the indigenes were nomadic pastoralists (Fieldhouse 1981:74). Land was described as 'waste land' when it was 'not yet the property of individuals, but liable to become so through the intervention of government' (Wakefield 1833, cited in Winks 1969:39). Imperial intervention on behalf of the 'natives' was then most urgently needed in land-intensive economies; yet where such colonies were distant from the metropolis, colonial policy was formed in favour of settler concerns, not of imperial interests or policy. The imperial authorities knew about settler atrocities in Basutoland in 1881 and in Southern Rhodesia in 1896-9 but did nothing. They did attempt to protect native' interests in South Africa, Rhodesia and Kenya, but not with notable success: 'native reserves' were created, supervised by British or colonial officials on tiny budgets, unable to become self-sufficient political or economic units; and in South Africa the reserves were the root of the later apartheid policy of the Union Government. The legacy of this half-hearted British attempt to protect 'native' interests came in the twentieth century. It was the land issue that sparked off the Rhodesian crisis in 1960, when African land grievances swelled into nationalism and the white government therefore proposed to abolish the Land Apportionment Act. The Rhodesian Front won power because it opposed any changes in the Act.

In the nineteenth and early twentieth century, then, it was frequently the settlers whose interests triumphed, with their 'frontier mentality of cultural arrogance, brutal force, rough-hewn 
individualism and disdain for the humanitarianism which at times permeated imperial policy' (Betts 1976:220). Even in the more centralised French empire the debate over whether to achieve development in Algeria by working through indigenous institutions (association) or by imposing French civilisation (assimilation) was coloured by the presence of large numbers of French civilians and military. These repudiated any idea of eventual equality with the 'natives' and it was partly the presence of white colons which prevented the majority of the colonised from 'becoming French' as the assimilationists had proposed (Ross 1982:4).

It would perpetrate too rosy a view of the metropolis to suggest that it was only white settlers who exploited and repressed the local population. Whether as settlers or as colonial administrators, Europeans were generally masters of the colonial situation. Even though administrators attained high professional standards and often were genuinely interested in defending 'native' interests, they sometimes acted for specifically European interests and were far too prone to treat their subjects like children (Fieldhouse 1966:376). Many imperialists were racist in their thinking about the very 'natives' they were attempting to defend against white settlers; and despite differences in official 'native policy' it made little overall difference whether these Europeans were British or French (or any other kind of European). The major empires imposed intensive control, adopted the concept of trusteeship for 'backward races' and assumed their empires would last forever. Hence the virtual autonomy of settler regimes was aided by the growth of racist ideas in the metropolis itself. For both the imperial power and settlers, a racist ideology served to justify capitalist exploitation and the destruction of indigenous economies and cultures; and when indigenous movements began to claim the right to self-determination, both imperialists and settlers denied the legitimacy of this claim: the colonised had no history; they owed 'loyalty' to those who had taken power over them; and their pretended 'nationalism' when it arose in the twentieth century was 'irrational' or the work of agitators.

The contradiction between metropolitan stated principles and actual failure to protect 'native peoples' against white settlers can be partly explained by something other than 'ties of blood': what they also had in common was that they were capitalist societies. Debates about whether 
capitalist societies were of necessity also racist and imperialist occupy much of the literature on imperialism; but it is clear that the great European empires were formed at a time when capitalism was rapidly becoming the dominant mode of production in Europe. The new emphasis on the creation of material wealth both inspired and financed colonial ventures as well as other foreign investment. The establishment of the principle of private ownership of property, including land, clashed with the widespread of communal tenure in the lands seized by the European powers and by settlers (Lemon \& Pollock 1980:85). Colonial conflict involved a clash between contradictory values, for in a capitalist system power comes from wealth (rather than, for example, wisdom or physical strength) and so it is the rich who exploit the poor; competition and individualism replace co-operative venture and the bonds of family, clan and community; and the emphasis is on money, personal gain and self-help (Gladwin 1980:25-6).

Britain's economic, strategic and foreign policy interests ultimately remained paramount above those of both 'natives' and settlers; but where there were no immediate conflicts of interest, the imperial government made no attempt fully to govern such colonies, at least up to the 1920s and in some cases beyond. Despite the principle of 'trusteeship', 'native policy' in the mixed colonies was largely dominated by settler interests. There were signs in the earlier part of the twentieth century that this situation might not last. In the inter-war years much parliamentary time was spent at Westminster on colonial issues, and this focused above all on the conflicting interests of settlers and 'natives' in British colonies. Churchill caused great resentment among Kenyan settlers by ruling in 1921 that forced labour could be employed only by permission of the Secretary of State; and white Rhodesian attempts to gain Dominion status for their colony failed to win acceptance. Despite imperial reservations, however, all the settlement colonies were eventually granted representative (that is, effectively settler) government, which usually meant a minimum of metropolitan interference. Thus from 1923 until 1953 the government of Southern Rhodesia remained firmly in the hands of the settlers, and their openly discriminatory 'native policies' were never challenged in Whitehall. The French case was rather different. Colonies were overseas territories of France, representation was in Paris, and the local body in Algeria gave 
settlers no legal control over any aspect of government; but settlers did influence French policy.

By and large, then, metropolitan interference with settler domination was, despite pious affirmations of the principle of trusteeship, minimal or non-existent until the 1920s and beyond. Imperial policy was racist in practice and largely indifferent to the well-being of its imperial subjects. It was accompanied by an ideology which attempted to legitimate the seizure of other people's lands and labour on the grounds of European superiority, notions of 'trusteeship' and a 'civilising mission'. So racism and pretensions to legitimacy were not confined to settler societies. It can, however, be demonstrated that in such societies they took - and still take - a particularly vehement form.

Good (1976:603) claims that initial settler violence towards the 'natives' sprang not out of racism or sadism but from the need to control their land and labour. Nevertheless, settlers developed a racist ideology which was different from metropolitan racism. Since any change in the balance of power in the colony would be against settler interests, the alleged inferiority of the 'natives' as a group was held to be either unchangeable or unlikely to be remedied in the foreseeable future. These notions of the immutability and universality of 'native' inferiority make it appropriate to speak of racism rather than ethnocentricity (Fanon 1967b:40). What is really noteworthy is that settler racism, in the form of structures, personal attitudes and behaviour, is similar everywhere, irrespective of the settlement's origins.

Settler racism differs from metropolitan racism because settlers are in actual contact with the 'inferior' peoples, in a colonial situation involving the subjection of a majority by a minority. This situation favours the settlers, and it is in their interests to maintain it. Its basis is coercion, or the threat of coercion, which is necessary to forestall any 'native' attempts at throwing off colonial domination. The peculiar nature of settler racism, therefore, arises out of fear.

However varied the group of settlers, they are united in the matter of the 'natives'. They are determined to retain their dominance, and individual settlers who have contrary views are often branded traitors by their own community (Hartz 1964:22). Memmi too has noted the difficulties for settlers who recognise the injustice of the situation: they have only two real choices, to 
emigrate or to stay and join a group seeking 'native' emancipation. The latter course is the more difficult: not only will they face hostility from their fellows, there are problems assimilating with the 'natives', whose culture may be very different. It is also difficult to avoid a trace of racism 'in a country where everyone is tainted by it' (Memmi 1974:23). The difficulties are compounded for left-wingers, because of their 'very intense doubts and real uneasiness in the face of the nationalistic form of (...) attempts at liberation' (Memmi 1974:28), by the left-wing tradition which abhors the use of violence for political ends and by the conservative social order that is often the aim of liberation movements. Racism in varying degrees, then, is endemic in the colonial situation; but it is generally the less-privileged settlers who are the most overtly racist, and these have a powerful voice in those settler societies which claim to subscribe to democratic (or, at least, populist) values. Their concept of democracy does not, however, extend to incorporation of the 'natives' (Kuper 1972:402-5).

Various ways are used to enforce settler domination. Coercion is the commonest way to establish a colony, but once set up there are always special laws intended to deter 'rebellion', and relations between settlers and 'natives' are based essentially on force. This was most apparent in Algeria where settlers were reinforced by the French Army. Coercive domination alone, however, is not enough if society is to function with some degree of normality. Hence 'structural' and 'psycho-social' domination also develop (Baker 1983:30).

Structural domination takes a variety of forms. Systems might be openly discriminatory, such as South African apartheid, or superficially 'non-racial' with all subject to the same laws, as in Rhodesia, where local authorities were left to decide the extent and type of segregation, absolving central government from any blame. The essence of structural domination, however, is that settlers have greater access to economic and political sources of power. At the same time, being wealthier and more powerful than the majority allows settlers to claim - and even to believe - that this is proof of their innate worth. This makes them more determined to keep a gap between themselves and the 'natives', as continued evidence of their right to dominance (Thornton 1965:188-9). 
This gives rise to psychosocial domination - essentially, the process by which a powerful group convinces both itself and the subordinate group that its superior character and worth gives them a right to power. It takes the form of setting up a mythical portrait of the 'natives'. This picture is usually shared by the metropolis to some extent but it takes a particularly vehement form in the settler colony. Groups like the Masai, when they were no longer a threat because their numbers were declining, were romanticised as 'noble savages' (Hughes 1963:104); but in general the portrait is insulting and contemptuous. It is often the character of the 'natives' which is allegedly inferior - or in some cases even non-human, as when Afrikaners referred to Africans as baboons (Lemon \& Pollock 1980:84). At the same time settlers set up a mythical portrait of themselves as custodians of civilised values and hence worthy of their privilege. The 'primitive Manichaeism of the settler' (Fanon 1967b:115) divides colonial society into two groups, the settlers representing good and the 'natives' evil. Real or imaginary differences are stressed, to the detriment of the 'natives'. Significantly, there is a large degree of similarity between the mythical portraits of different sets of 'native peoples'. The commonest slur is laziness, supplemented by inefficiency, lack of ambition, ingratitude, deviousness, childishness, moral laxity, emotionality and superstition. They are easily manipulated by their traditional culture or leaders, and are prone to violence.

Not only does this portrait excuse settlers' usurpation of land and domination but in particular the accusation of laziness has been used to justify forced labour (Alatas 1978:2). Memmi (1974:79-82) uses several examples to illustrate this self-justification. The 'laziness' of the 'natives' contrasted with the 'industriousness' of the settlers justifies the latter's privileged position and the former's poverty; their 'weakness' justifies the establishment of a protectorate over them; their 'wickedness' justifies the police force and legitimates the severity of the system; since the 'natives' seem not to worry about their poverty, the settlers are absolved from making it their concern, especially as any attempts to help on the part of the settlers are likely to result only in 'ingratitude'.

The portrait is never totally without foundation, for if it were its falsity could soon be 
demonstrated; but whatever the 'natives' might have been before the settlement, the colonial situation itself encourages a lack of interest in the type of work available. Allport (Sunar 1978:517) claimed that dishonesty and deviousness are typical traits of the victim; and the colonial situation inevitably creates violence, among the 'natives' as well as against the settlers (Austin 1983:94-5). Nevertheless, whatever grain of truth there may be in the mythical portrait of the 'natives', it is still essentially mythical - the embodiment of popular ideas rather than an objective description.

'Native' culture, language, religious beliefs and practices, law and customs are similarly denigrated (Fanon 1967a:14), and attempts have been made to destroy it. Arabic was deemed a foreign language in Algeria and not taught in schools until 1947 (Guérin 1973:275). More frequently, however, the local culture has affected settlers, and settler societies develop a hybrid culture, different from that of the metropolis but not thoroughly assimilated into the 'native culture' (Lemon \& Pollock 1980:81). On the whole, however, the gap between settlers and 'natives' is conveniently maintained by the cultural gap. Cultural denigration necessarily varies in its content according to the nature of the 'native society'. Raffles claimed that Malay society was backwards and Malays were intellectually inferior, on the grounds that they had no well-defined system of law, they were Muslims, they had previously been under Hindu influence and they tolerated the vices of their rulers (Alatas 1978:39).

A typical portrait of a 'native culture' is presented by a Rhodesian settler at the time of the Unilateral Declaration of Independence (UDI). It is no longer respectable to argue for biological inferiority (Fanon 1967b:31-2), and Peck (1966:7, 52-3, 59-63, 163) claims that culture, not skin colour, divides 'natives' from settlers. He describes the indigenous population at the time of early European settlement as illiterate, technologically two thousand years out of date, dirty, ignorant of money and all but rudimentary medicine, confirmed believers in witchcraft, lacking in common competence and uncivilised. It is clear that Peck thought little had changed or was likely to do so for a very long time.

One aspect of cultural denigration is the negation or re-writing of the colony's history before 
its conquest: only settlers make history (Fanon 1967c:39-40). One historical fact, however, that was hard to deny was the conquest of territory that 'began' the history of the colony. This was a clear act of usurpation which colonisers needed to transform into legitimacy. For Memmi (1974:52) this creates a problem of conscience for settlers, evidenced by their strenuous insistence, strange for a victor, on apparently futile matters. He endeavours to falsify history, he rewrites laws, he would extinguish memories - anything to succeed in transforming his usurpation into legitimacy'. This unacknowledged and never-resolved guilt explains for Memmi and other observers the peculiarly vicious and enduring form of racism in a colony, and the rage with which the settlers attack the 'natives', verbally if not physically.

The greatest source of stress is fear of the 'natives'. That a group so despised should be so feared is one of the contradictory features of the mythical portrait of the 'natives'. This fear has a variety of roots. Settlers fear their culture being 'swamped' by 'native' culture, and this fear usually heightens group solidarity, as do threats of economic competition. Settlers rightly assume that the 'natives' want to take their place; and, despite stereotypes of the 'lazy native', this threat can be real. The efficiency of African farmers in South Africa posed a threat which was banished only by discriminatory legislation (Baker 1983:82-3). Another fear is of 'native' sexuality and dilution of the 'superior' race through 'interbreeding' (Ridley 1983:74-90). Fear arises above all, however, from the possibility of the 'natives' attaining any degree of power and, in the twentieth century, of decolonisation and subsequent exile. Hence the greatest fear is of 'native aggression' leading to loss of power and of the stolen lands. So the stereotype of the 'native's' passionate, even violent, nature adds fear and distrust to contempt, and when the 'natives' strike back this is merely proof of their savage nature. They cannot insult and intimidate the settlers in return for racism as an institution depends on an unequal distribution of power. Not all of the 'natives' are considered rebellious or ungrateful, but agitators serving their own ends are claimed to have malign influence on 'natives' who would otherwise behave themselves (Porter 1975:181).

The subconscious knowledge that force alone would be insufficient if there were a 'native revolt' makes psychosocial and structural domination all the more important: hence the alarm, 
anger and panic which greets any attempt at 'native' emancipation (Mannoni 1964:87). It is not surprising that this fear is the most likely to enhance group solidarity and generate a 'siege mentality'. Whether it is their culture or their persons that settlers believe are under threat, they take extreme measures to ensure their survival when the threat reaches a climax (Baker 1983:115-6). Until then the siege mentality may be manifested in a physical sense such as the Boer laager or psychologically by imposing social and political barriers against the 'natives'. In most settler societies these threats from the 'natives' have indeed materialised, and have been publicised by the world media; and the conflict has been the more bitter because the settlers' behaviour is 'a composite of fear and rage' (Thornton 1978:303). As a result, events crystallise race prejudice so that most settlers are paralysed into an inability to think intellectually, consider change or admit past mistakes (Fanon 1965:167-8).

It is true that some individuals may cross the barriers and become assimilated into the settler group, but it is impossible for the whole group to rise, for this would end the colonial situation. It may even be of advantage to allow some 'natives' to attain greater status. They may be needed for the lower ranks of administration, policing and so on, or this may allow the settlers to deny charges of discrimination. They can point out that merit is rewarded in their society and claim that those who do not succeed are lazy or unambitious. The rise of some individuals (and indeed the kindness and concern of some settlers) does not, however, change the overall picture: 'a collective drama will never be settled through individual solutions' (Memmi 1974:126). Furthermore, even where the 'natives' have formal equality they may be informally excluded from full participation: 'The boundaries may shift but must always be retained, or the colonial situation loses its meaning and ceases to exist' (Mirande 1978:297).

Military philosophy applied to 'native revolts' in imperialist thinking holds that leniency is interpreted as timidity and the swiftest and most decisive way of putting down such revolts is 'the knock-out blow'. The laws of war among civilised nations do not apply to warfare against 'native 
peoples'. The British metropolis, however, which needed no standing army to guard its frontiers, could afford to be more 'liberal' in outlook, and used force less than other empires (Kiernan 1982:111), but for settlers in mixed colonies, ethics were a luxury, and even non-hostile 'natives' could not be conceded the same rights as settlers nor their lives the same value. Instead, the thoughts and actions of settlers and their descendants were conditioned by the necessity to ensure the success and continuing stability of the colony, and their main aim to keep what they had inherited, together with whatever their own efforts had added (Thornton 1965:188). Settlers knew that without their own efforts, however brutal they might be, the 'natives' might be able to take over power - and they would exercise it in their own interests. There was then a divergence of attitude between those living in the safety of the metropolis and those living in a 'perpetual state of emergency', whether actual or potential, and several writers have commented on the continuation and prevalence of violence in colonial situations after the initial, usually violent, expropriation of land from the 'natives'.

For settlers the violence of the 'natives' was inherent in their nature, and violence was not a result of colonisation but a valid reason for seizing the territory in the first place. The only defence against 'native' violence was more violence. Power could not be shared with the colonised since they could not be trusted; so it must be monopolised and defended by force if necessary. Frequently the mere possession by settlers of superior force was sufficient to deter revolt (Memmi 1974:93), but when they did attack, 'natives' were accused of cowardice, because the most appropriate form of attack, given their inferior resources, was guerrilla warfare involving hit-and-run tactics and often civilian targets. This kind of violence was denied legitimacy whereas the violence carried out by the state and bolstered by imperial law was seen as legitimate defence.

Another settler claim was that troublemakers formed only a minority of a generally contented 'native population' - so the solution was simply to eradicate the troublemakers. The often-quiescent behaviour of most 'natives' and their conformity, which is easily understood in the context of their powerlessness, was taken for acceptance (Berreman 1972:407). A 
contradictory settler perception, however, was that any form of protest, however mild, was ultimately aimed at destroying settler power; hence all popular movements were aborted and where possible destroyed.

The great majority of writers on settler societies are critical of them. Such societies contain distortions, even pathologies. Not only does simple justice demand the end of the colonial system, but the contradictions within the system and the subconscious and destructive guilt of the settlers make colonised societies, which are symbolised by racism, diseased and incapable of reform. Such a society is doomed to 'slowly drift away as a closed system, toward a condition of total meaninglessness' (Lanternari 1980:60). Hartz (1964:21-2), however, more optimistically believes that modern communications are such that societies of this type can no longer remain closed and will perforce change.

The settler rebellions in Algeria and Rhodesia were among the major problems that settlers created for the metropolis. Both were exacerbated by the notion of 'kinship' between settlers and their metropolis (although it should be noted that in each case large numbers of the settlers had their origins outside the nominal 'mother country'). Emmanuel (1972:40) argues that the greatest problems for the British imperial power from the nineteenth century were its struggles with settlers and not with the 'natives', but this view devalues the resistance to imperial rule, from Ireland to India. Indeed, it was the successful resistance to French rule in Indo-China that made the French army determined to hold Algeria. In the event, the settlers' dream of autonomy was, for most of those in countries where they formed a visible minority, eventually to end. The latest example is South Africa.

Metropolitan enthusiasm for empire was never universal, and it waxed and waned in Britain from the mid-nineteenth century onwards. There was even more antagonism to empire in France, though in the end empire was seen as a counterbalance to German might (Nadel \& Curtis 1964:17-18). In both cases imperial rhetoric was not matched by actual expenditure on improving 
the lives of colonial subjects nor by giving them real liberty and equality. In Britain and France, most people were ignorant both of imperial policies and of the conditions in the imperial possessions. Only slavery aroused real public interest, and empire aroused real emotion only when imperialism was popularised among the British masses, above all by the cheap newspapers catering for the newly-literate towards the end of the century. After the 'scramble for Africa' of the 1880s, there was a brief age of self-conscious imperialism when the British empire was vaunted as the strongest, largest and most benign the world had ever seen, and flags and banners became sacred symbols of the nation which now seemed to dominate the world (Thornton 1965:85).

Much of this was already illusion. Britain's economy was falling back in the world, her army was inadequate to defend such a huge empire and she was diplomatically isolated (Porter 1975:124). The greatest rhetorical excesses of imperialism occurred only shortly before the shaming outcome of the Boer War. Recruitment had revealed the poor physical quality of the British and the near-defeat by people regarded as nothing more than farmers exposed fundamental weakness in imperial might. Those who had dreamed of a liberal and humanitarian empire were disillusioned too, by the abandonment of South Africa to its white settlers (Huttenback 1975:96). By the 1930s, after the 191418 war and the economic miseries which followed, there had been a resurgence of ideas about the equality of all peoples (Fieldhouse 1966:378). This ideological change in the metropolis was not mirrored by change in the settler colonies, and the strains in the settlermetropolis relationship became worse in the twentieth century:

As the nineteenth century developed, this world of high policy grew ever more sophisticated and even more impatient with the obscurantism of primitives, whether white colonials or savages, who did not because they could not keep pace with its own kind of progress ... The improvements in world communications served only to emphasise this time lag in ideas, attitudes and practices between the metropolis and the colonial outpost (Thornton 1965:60).

A number of studies has observed the resistance to change in settler societies compared with the 
metropolis. Memmi (1974:98-9) describes the life of the colony as 'frozen ... its structure is both corseted and hardened ... a mask under which it slowly smothers and dies ... unable to be transformed'. Hartz (1964:6-7) explains this rigidity as the result of the hardening of early values to form a national value-system to which later immigrants conformed. Mannoni (1964:128) complains of a lack of originality and creativity, which Thornton (1965:43) explains by the small size and close-knit relationships of settler societies, such that anyone who aired radical or even innovative views might be thought disloyal and excluded from social life. Above all, continuance of the settlement depended precisely on the absence of change, both in the colony and in the metropolis which sustained it.

Dislike of change has been associated with higher than usual degrees of suspicion, rigidity, compulsiveness and anxiety (Austin 1977:31). A situation which breeds uncertainty, as the settler-'native' relationship does, is likely to produce individuals given to conservatism, reaction or even fascism, as they can support only governments that maintain the status quo, or in other words the framework of oppression (Memmi 1974:55-6). However, the root of settler conservatism and dislike of left-wing metropolitan governments can most plausibly be linked to a fear of political change that threatens settler interests. This fear is rational, for the greatest threat to settlers has been metropolitan acquiescence in independence under majority, that is, 'native', rule, though right-wing as well as left-wing imperial governments have 'betrayed' their settlers.

Decolonisation started between the world wars, when most of Ireland, excepting the majority of its settler community, broke away in a welter of violence while the white settler colonies of Canada, Australia, New Zealand and South Africa, which had loyally supported Britain in the war, were peacefully translated by the 1931 Statute of Westminster into Dominions with the power to make their own laws. There were serious disturbances in 1919-20 in Egypt, the Punjab and Iraq by nationalists for whom the war had revealed the weakness at the heart of empire. They, however, were not strong enough to exploit the situation, despite the revival of Liberal antiimperialism in Britain; and immediately before the second world war, despite the gathering force 
of resistance movements, particularly in India, neither Paris nor London thought selfdetermination for other imperial possessions was inevitable or imminent.

The 1939-45 war, however, inevitably changed things, even if some were slow to realise this: Leo Amery complained in 1944 that the BBC overseas services were creating the impression that Congress was entitled to speak for all India; and the post-war government devised a scheme, to run for forty-four years, to settle ex-soldiers in Kenya. Yet in 1947 India, Britain's largest and most prestigious colony, became the first of many independent members of the newly created British Commonwealth. This new phase of decolonisation was, however, a reaction to uncontrollable events rather than a policy, however much the British might claim that the transformation of empire into Commonwealth had always been its intention (Thornton 1978:280).

One of these uncontrollable factors was the further tarnishing of the image of imperialism in the eyes of colonial subjects. The savagery of the war on both sides sat uneasily with the notion of the civilising mission, and any kind of imperialism was a negation of the freedom for which the war had ostensibly been fought. Africans were not slow to see the implications of their own role in the war, when they had been taught to kill white men (Kiernan 1982:189). Most important perhaps was the fact that Britain no longer had either the military capacity, the economic strength or the prestige to hold its reluctant empire, especially in the face of American and United Nations political opposition. There had long been guilt in liberal quarters at the disparity between domestic principles of liberty and the right of nations to self-determination; and the British Labour Party, steadily increasing its influence, had always taken an anti-imperialist line, even if it became more cautious about the timing of decolonisation as its accession to power became more likely (Robinson 1965:59). There was relatively little difficulty, then, in imperial ideology adapting to changed circumstances, especially with the invention of the Commonwealth.

The idea of empire was not given up immediately. The creation of two federations in Africa and one in southern Arabia was intended to retain British power there for a period at least. In Africa each federation consisted of one white settler state and two with little white settlement, which would gradually move towards some kind of independence guaranteeing whites an assured 
future. Gradualism was, however, unacceptable to nationalists. The Suez adventure of 1956, one of the last stands of imperialism, ended in ignominious retreat for the British and French forces in the face of furious opposition not only from the USA but from India and Canada; and in the end Macmillan's 1959 government resolved to depart as advantageously as possible from Africa, without overmuch concern whether indigenous political elites would be able to run the new states with the inadequate resources bequeathed them (Thornton 1978:283). The strategic motive for empire, however, was still important and the Aden revolt in 1964 was treated with severity against both militants and the civilian population (Kiernan 1982:211).

The French did not give up easily either. The war had split metropolitan France, which had effectively lost control over French North Africa, Syria and the Lebanon to the Anglo-American command. French pride, severely dented by the Vichy years, required the maintenance of empire. Coercion was the rule, and in 1945 40,000 Arabs were massacred in an 'Arab hunt' (Fanon 1965:176). The creation of the French Union, consisting of all its possessions united into the French Republic, was an attempt to avert the end of empire. All of the Union's residents became French citizens, and the protectorates of Tunisia and the Union of Indochina also had full autonomy except in foreign policy. The new citizens, however, were not convinced that anything had really changed. The regular army, which had carved out France's African empire, committing atrocities from the first against the ever-present 'native' resistance in Algeria, was still imbued with Vichy ideology and anxious to avenge its wartime humiliation. The professional army, which opposed decolonisation to the last, carried out a massacre in Madagascar and waged vicious colonial wars in Indo-China and Algeria, giving substance to the fears of the colonial 'citizens'. Then in 1958 de Gaulle transformed the Union into the Community, and within a few years all but a few of the smaller possessions were politically independent.

We cannot speak of a straightforward dichotomy between settlers resisting and metropolis insisting on decolonisation. Even in the 1920s, those who sought to prevent white settler self- 
government in Kenya included 'mavericks among the white settler pack, who provided a steady stream of informed and lethal ammunition in books and articles and pamphlets' (Porter 1975:274). After the 1939-45 war there were those in white settlement colonies who welcomed or accepted decolonisation and the loss of white power (Hancock 1984:passim). Metropolitan reactions to settler opposition were mixed and certainly some in the metropolis opposed decolonisation. It is fair to say, however, that, setting aside the special case of the French army, the bitterest opposition to decolonisation came from settlers threatened by it. Now the enemy consisted not only of the 'natives' but also the metropolis.

The metropolis certainly bore much responsibility for the situation in the mixed colonies. It was the artificial conditions of the empire that had allowed settler communities to take strong root and retain their dominance. Protected by the authority of the metropolis, they had no need to assimilate to the host community as minorities are usually constrained to do; but there was always indigenous opposition, and it was no accident that three of the world's main trouble spots in the 1970s, Northern Ireland, Israel and Rhodesia, could be directly attributed to the British empire's original interference with smaller and weaker communities than itself and the incursion of settlers (Porter 1975:348).

The resulting troubles were hardly new, however: settlers had always tended to defy metropolitan demands for reform. The Spanish colonists decided to sever their ties with Spain in the nineteenth century when ideas of progress for all led to a demand for drastic reforms in the colonies, in a very similar way to Rhodesia's UDI much later in 1965 (Gladwin 1980:8). The situation was further exacerbated when the mother country or powerful groups within it supported their colonists, as in both the Algerian and Rhodesian cases. These mixed messages from the metropolis gave settlers some grounds for hope that they might be allowed to keep their gains. French colonialism in particular was based on the assumption that it would last forever and the British seemed unable to hold a consistent line on, for example, the future of Kenya. Despite the Devonshire Commission's proclamation in 1923 that Kenya was an African territory, Kenyatta was not allowed to testify before the Hilton Young Commission in 1929, which returned to the 
principle of trusteeship. The long history of unrest from this time, culminating in the emergency in 1952, did not prevent the settlers in a handbook of 1949 from portraying Kenya as an ideal settlement area (Winks 1969:125-6). Clearly they did not believe that the British would cease to support them, and the behaviour of the police during the uprising, which has been compared with that of Nazi Germany or Japan, seemed to confirm their hopes (Kiernan 1982:221). In the event the white community was too small to survive alone, and concern at the repression, in Britain as well as other Commonwealth countries such as India, led to Kenyan independence under majority rule being granted in 1963, despite bitter settler opposition.

The Southern Rhodesians, however, formed a larger and more powerful group, and even though their daily lives were shadowed by guerrilla warfare, their independence survived as long as South Africa underwrote it. Despite these factors, metropolitan ambivalence about decolonisation is thrown into relief by reactions to the Rhodesian settlers' defiance. A Labour government was in power, but few, even among the most anti-imperialist, advocated the use of force against settlers, and this fact was noted by Africans who remembered that Britain had shown less hesitation when Africans or Asians rebelled. Conservative opposition to force was predictable. The recent release of official documents has revealed that the Labour government was advised by 'experts' that force would fail, and since 1912 in Ulster the obedience of the officer corps of the British army could not be relied on. Similar trends had been apparent in the Algerian crisis. The French attempts at repression, on a bloodier scale by far than most British equivalents, continued throughout socialist as well as right-wing governments, and they culminated in the revolt of part of the army in favour of the settlers.

Despite this ambivalence, it is clear that formal empires are no longer fashionable and whatever lingering nostalgia for empire on the part of the British or French still exists, the open retention of colonial possessions without economic or strategic significance is no longer on the political agenda. 